TABLE 7. Boiling-point elevation of dextrose solutions

\begin{tabular}{|c|c|c|c|c|c|c|}
\hline \multicolumn{7}{|c|}{$\log \Delta t=\alpha+\beta C+\gamma C^{2}+\delta C^{3}$} \\
\hline Pressure & $\alpha$ & $\beta$ & $\gamma$ & $\delta$ & $\begin{array}{l}\text { Average } \\
\text { deviation }\end{array}$ & $\begin{array}{c}\text { maximum } \\
\text { deviation }\end{array}$ \\
\hline $\begin{array}{r}m m \mathrm{Hg} \\
233.72 \\
355.22 \\
525.86 \\
760.00 \\
1,074.58 \\
1,489.14\end{array}$ & $\begin{array}{r}-0.989843 \\
-.982743 \\
-.967871 \\
-.944029 \\
-.918243 \\
-.885843\end{array}$ & $\begin{array}{l}\text { 5. } 113375 \times 10^{-2} \\
\text { 5. } 191070 \\
\text { 5. } 239106 \\
\text { 5. } 235447 \\
\text { 5. } 251193 \\
\text { 5. } 225459\end{array}$ & $\begin{array}{l}-7.377463 \times 10^{-4} \\
-7.435453 \\
-7.477459 \\
-7.427223 \\
-7.490898 \\
-7.476027\end{array}$ & $\begin{array}{l}\text { 5. } 526503 \times 10^{-6} \\
\text { 5. } 463234 \\
\text { 5. } 427242 \\
\text { 5. } 345987 \\
\text { 5. } 396036 \\
5.404016\end{array}$ & $\begin{array}{l}{ }^{\circ} \mathrm{C} \\
\pm 0.017 \\
\pm .023 \\
\pm .028 \\
\pm .031 \\
\pm .033 \\
\pm .033\end{array}$ & $\begin{aligned} &{ }^{\circ} \mathrm{C} \\
&+ 0.032 \\
&+ .045 \\
&+ .055 \\
&+.061 \\
&+.067 \\
&+.067\end{aligned}$ \\
\hline
\end{tabular}

are useful, however, in calculating the boiling point elevations of dextrose solutions to within $0.05^{\circ}$ to $0.1^{\circ} \mathrm{C}$.

Molal boiling point elevations of aqueous solutions of dextrose have been measured by Juettner [8], but only at normal atmospheric pressure. A com-

TABLE 8. Molal boiling-point elevation of dextrose solutions $(760 \mathrm{~mm} \mathrm{Hg})$

\begin{tabular}{|c|c|c|}
\hline Molality & Juettner [8] & This paper \\
\hline $\begin{array}{l}1 \\
2 \\
3\end{array}$ & $\begin{array}{c}{ }^{\circ} \mathrm{C} / \text { mole } \\
0.53 \\
.53 \\
.53\end{array}$ & $\begin{array}{c}{ }^{\circ} \mathrm{C} / \text { mole } \\
0.520 \\
.525 \\
.531\end{array}$ \\
\hline $\begin{array}{l}4 \\
5 \\
6\end{array}$ & & $\begin{array}{l}.537 \\
.544 \\
.552\end{array}$ \\
\hline $\begin{array}{l}7 \\
8 \\
9\end{array}$ & - & $\begin{array}{l}.561 \\
.570 \\
.580\end{array}$ \\
\hline
\end{tabular}

parison of his values with those of this investigation is given in table 8. Apparently, there are no other published measurements of the vapor pressures of aqueous solutions of dextrose in the range reported in this paper.

\section{References}

[1] N. S. Osborne, H. F. Stimson, and D. C. Ginnings, J. Research NBS 23, 261 (1939) RP1229.

[2] E. R. Smith, J. Research NBS 24, 229 (1940) RP1280.

[3] G. W. Thomson, Chem. Rev. 38, 1 (1946).

[4] F. J. Bates and Associates, Polarimetry, saccharimetry, and the sugars, NBS Circular C440, p. 365 (1942).

[5] W. Swietoslawski, Ebulliometry (Reinhold Publishing Corp., New York, N.Y., 1945).

[6] H. S. Isbell and W. W. Pigman, J. Research NBS 18, 178 (1937) RP969.

[7] E. R. Smith and H. Matheson, J. Research NBS 20, 641 (1938) RP1097.

[8] F. Juettner, Z. physik. Chem. 38, 76 (1901); Int. Crit. Tables III, 327 (1928).

Washington, July 17, 1950 。

\title{
Wavelengths for Calibration of Prism Spectrometers
}

\section{By Earle K. Plyer and C. Wilbur Peters ${ }^{1}$}

\begin{abstract}
Several absorption bands of polystyrene, 1,2,4-trichiorobenzene, and other compounds have been measured in the infrared region from 1.5 to $24 \mu$ on grating spectrometers. These bands have been determined with sufficient accuracy for use in calibration of prism instruments. A table is included that gives the cell thicknesses used in the measurements. The emission lines of mercury for the region from 0.5 to $2.4 \mu$ are included. In order that the table may be of most value, a number of bands that have been determined by previous observers have also been included.
\end{abstract}

Many infrared absorption bands have been carefully measured, and their reported wavelengths $[1]^{2}$ are useful for calibrating spectrometers. Techniques of calibration utilizing vibrational bands with resolved rotational structures, including those of ammonia, carbon dioxide, and water vapor, have been described by Oetjen, Kao, and Randall [2]. When one undertakes to calibrate an infrared spectrometer he soon finds that additional reference lines or bands would be extremely helpful and that the information available has some serious disadvantages. In certain regions there are an insufficient number of

\footnotetext{
1 University of Michigan.

Figures in brackets indicate the literature references at the end of this paper.
}

standards. In some cases where a band has a rotational fine structure that is not resolved by a prism, it is not possible to locate any individual band with sufficient precision to justify its use for calibration. Furthermore, some absorbing materials require impractically long absorption cells. To avoid these disadvantages and increase the number of calibration points, additional lines and bands in the region from the visible to $24 \mu$ have been measured by using sources or absorbers convenient for the calibration of prism instruments. These include: (1) polystyrene films and trichlorobenzene, which prove standards between 15 and $24 \mu$; (2) $\mathrm{AH}-4$ mercury lamp in the region visible to $24 \mu$; (3) toluene at $21.5 \mu$; 
(4) methylcyclohexane [3], 7 to $12 \mu$. Wavelength data on all except the mercury source were obtained in order to meet the objectives of this investigation.

This information, combined with previously reported values for carbon dioxide, methane, water vapor [1], and methanol [4], form a reasonably complete set of secondary calibration points, supplementing the bands of ammonia and water vapor now in use.

All the measurements recorded in table 1 and marked on the characteristic spectra that follow were made with grating instruments. Those in the region 1 to $3 \mu$ were made at the National Bureau of Standards with a 15,000-line-per-inch grating and lead sulfide detector. The polystyrene bands in the $3.4-\mu$ region were measured for the authors on the Ohio State University grating spectrometer by John $\mathrm{S}$. Burgess. The bands from 3.6 to $24 \mu$ were measured by the authors at the University of Michigan. These grating measurements are the basis for the values marked on the characteristic spectra shown in figures 2 to 8 . The characteristic spectra as shown in figures 1 to 6 were taken with an appropriate prism instrument.

In making the grating measurements, the resolution was adjusted to be of the same order as that obtained from good prism spectrometers for the region appropriate to a given optical material. Fairly wide slits were therefore required. The band positions were determined with a constant-energy background continuum to avoid the confusing shift that occurs when the background is not constant, that is if the spectral energy record shows a steep slope, the apparent positions of absorption minima may be shifted from the correct wavelength.

The bands shown in figures 2 and 4 have been measured with high resolution, so that an accuracy to $\pm 2 \mathrm{~A}$ could be obtained. For the calibration of instruments using lithium fluoride prisms, this degree of accuracy is desirable.

In the spectral region from 4 to $14 \mu$, the grating measurements have been made to $0.001 \mu$ of the wavelength value, and from 14 to $24 \mu$ to $0.01 \mu$. The following paragraphs give a more detailed account of the procedures in handling the experimental materials and an explanation of specific features of the graphic and tabular data.

Figure 1 shows the mercury lines, and the wavelengths recorded in table 1 have been supplied by Curtis J. Humphreys of this Bureau from his measurements and those of other investigators [5]. These spectra were recorded with a Perkin-Elmer 12-A spectrometer with a lithium fluoride prism. The lines were measured with different slit widths, but the drum readings of the maximum intensity of a line did not vary appreciably with the slit width when the lines were not complex. In the table, lines that were not resolved are joined by brackets, and the wavelengths given on the curve are the average values for these groups of lines.

The polystyrene films are made by first preparing a 10-percent solution of polystyrene in toluene and pouring some of this solution on a smooth, clean
TABLE 1. Calibration wavelengths for prism spectrometers

\begin{tabular}{|c|c|c|c|c|}
\hline $\begin{array}{l}\text { Wave- } \\
\text { length }\end{array}$ & $\begin{array}{c}\text { Wave } \\
\text { number } \\
\text { vac. } \\
\mathrm{cm}^{-1}\end{array}$ & State & Description & Substance \\
\hline $\left.\begin{array}{r}\mu \\
0.54607 \\
.57696 \\
.57907 \\
1.01398 \\
1.12866\end{array}\right\}$ & \begin{tabular}{r|}
18307.8 \\
17327.5 \\
17264.4 \\
9859.4 \\
8857.7
\end{tabular} & $\begin{array}{r}\text { Emission } \\
\text { do }\end{array}$ & $\begin{array}{r}\text { AH-4 lamp } \\
\text { do } \\
\text { do do } \\
\text { do }\end{array}$ & $\begin{array}{c}\text { Mercury. } \\
\text { Do. } \\
\text { Do. } \\
\text { Do. } \\
\text { Do. }\end{array}$ \\
\hline $\begin{array}{l}1.35703 \\
1.36728 \\
1.39506 \\
1.52952 \\
1.6606\end{array}$ & $\begin{array}{l}7367.0 \\
7311.0 \\
7166.3 \\
6536.2 \\
6020.3\end{array}$ & $\begin{array}{l}\text { do } \\
\text { Liquid } \\
\text { do } \\
\text { do }\end{array}$ & \begin{tabular}{|c|} 
do \\
do \\
do \\
$0.5 \mathrm{~mm}$ cell
\end{tabular} & $\begin{array}{l}\text { Do. } \\
\text { Do. } \\
\text { Do. } \\
\text { Do. } \\
\text { 1,2,4-Trichloroben- } \\
\text { zene. }\end{array}$ \\
\hline $\begin{array}{l}1.692029 \\
1.69419 \\
1.70727 \\
1.71099 \\
1.81307\end{array}$ & $\begin{array}{l}5908.5 \\
5900.9 \\
5855.7 \\
5843.0 \\
5514.0\end{array}$ & $\begin{array}{l}\text { Emission } \\
\text { do }\end{array}$ & $\begin{array}{c}\text { AH-4 lamp } \\
\text { do do }\end{array}$ & $\begin{array}{l}\text { Mercury. } \\
\text { Do. } \\
\text { Do. } \\
\text { Do. } \\
\text { Do. }\end{array}$ \\
\hline $\begin{array}{l}1.97009 \\
2.1526\end{array}$ & $\begin{array}{l}5074.5 \\
4644.2\end{array}$ & Liquid & $0.5-\mathrm{mm}$ cell & $\begin{array}{l}\text { Do. } \\
1,2,4 \text {-Trichloroben- }\end{array}$ \\
\hline $\begin{array}{l}\text { 2. } 24929 \\
2.3126\end{array}$ & $\begin{array}{l}4444.6 \\
4322.9\end{array}$ & $\begin{array}{l}\text { Emission } \\
\text { Liquid.... }\end{array}$ & $\begin{array}{l}\text { AH-4 lamp_... } \\
0.5-\mathrm{mm} \text { cell }\end{array}$ & $\begin{array}{l}\text { Mercury. } \\
1,2,4 \text {-Trichloroben- }\end{array}$ \\
\hline 2.32542 & 4299.1 & Emission & $\mathrm{AH}-4$ lamp & Mercury. \\
\hline 2.4030 & 4160.3 & Liquid... & $0.5-\mathrm{mm}$ cell & 1,2,4-Trichloroben- \\
\hline $\begin{array}{l}2.4374 \\
2.4944 \\
2.5434 \\
2.7144\end{array}$ & $\begin{array}{l}4101.6 \\
4007.9 \\
3930.6 \\
3683.0\end{array}$ & Vapor... & $\begin{array}{l}\text { do } \\
\text { do } \\
5.0 \text {-cm cell }\end{array}$ & $\begin{array}{l}\text { Do. } \\
\text { Do. } \\
\text { Do. } \\
\text { Methanol. }\end{array}$ \\
\hline $\begin{array}{l}\text { 3. } 2204 \\
\text { 3. } 2432 \\
\text { 3. } 2666 \\
\text { 3. } 3033 \\
3.3293\end{array}$ & $\begin{array}{l}3104.4 \\
3082.6 \\
3060.5 \\
3026.5 \\
3002.8\end{array}$ & 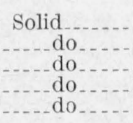 & 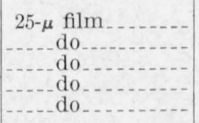 & $\begin{array}{l}\text { Polystyrene. } \\
\text { Do. } \\
\text { Do. } \\
\text { Do. } \\
\text { Do. }\end{array}$ \\
\hline $\begin{array}{l}3.3101 \\
\text { 3.4188 } \\
3.5078 \\
4.258 \\
4.866\end{array}$ & $\begin{array}{l}3020.3 \\
2924.2 \\
2850.0 \\
2349.3 \\
2054\end{array}$ & $\begin{array}{l}\text { Gas_.... } \\
\text { Solid do } \\
\text { Gas } \\
\text { Vapor }\end{array}$ & $\begin{array}{l}5.0-\mathrm{cm} \text { cell } \\
25-\mu \text { film } \\
\quad \text { do } \\
\text { Atmospheric } \\
5-\mathrm{cm} \text { cell }\end{array}$ & $\begin{array}{l}\text { Methane. } \\
\text { Polystyrene. } \\
\text { Do. } \\
\text { Carbon dioxide. } \\
\text { Methanol. }\end{array}$ \\
\hline $\begin{array}{l}5.138 \\
5.549 \\
6.238 \\
6.692 \\
7.268\end{array}$ & $\begin{array}{l}1945.8 \\
180.6 \\
1602.7 \\
1494.9 \\
1375.5\end{array}$ & $\begin{array}{l}\text { Solid } \\
\text { do } \\
\text { do.... }\end{array}$ & $\begin{array}{l}50-\mu \text { film } \\
\text { do do } \\
0.05-m m \text { cell }\end{array}$ & $\begin{array}{l}\text { Polystyrene. } \\
\text { Do. } \\
\text { Do. } \\
\text { Do. } \\
\text { Methylcyclohexane. }\end{array}$ \\
\hline $\begin{array}{r}9.672 \\
9.724 \\
11.035 \\
11.475 \\
11.862\end{array}$ & $\begin{array}{r}1034.2 \\
1028.1 \\
906.0 \\
871.3 \\
842.8\end{array}$ & $\begin{array}{l}\text { Vapor } \\
\text { Solid } \\
\text { Liquid } \\
\text { do }\end{array}$ & $\begin{array}{l}\text { 5-cm cell } \\
50-\mu \text { film } \\
0.05-\mathrm{do} m \text { cell }\end{array}$ & $\begin{array}{l}\text { Methanol. } \\
\text { Polystyrene. } \\
\text { Do. } \\
\text { Methylcyclohexane. } \\
\text { Do. }\end{array}$ \\
\hline $\begin{array}{l}13.883 \\
\text { a14. } 29 \\
14.98 \\
15.48\end{array}$ & $\begin{array}{l}720.5 \\
699.6 \\
667.3 \\
645.8\end{array}$ & $\begin{array}{l}\text { Gas } \\
\text { Solid......... } \\
\text { Gas } \\
\text { Liquid...... }\end{array}$ & $\begin{array}{l}\text { Atmospheric } \\
\text { 50- } \mu \text { film } \\
\text { Atmospheric } \\
0.05 \mathrm{~mm}\left(1: 4 \mathrm{CS}_{2}\right)\end{array}$ & $\begin{array}{l}\text { Carbon dioxide. } \\
\text { Polystyrene. } \\
\text { Carbon dioxide. } \\
\text { Unknown in techni- } \\
\text { cal grade of } 1,2,4- \\
\text { trichlorobenzene. }\end{array}$ \\
\hline a17. 40 & 574.5 & ..... do _. & $.025-\mathrm{mm}$ cell $\ldots$ & $\begin{array}{l}\text { 1,2,4-Trichloroben- } \\
\text { zene. }\end{array}$ \\
\hline $\begin{array}{l}\text { 18. } 16 \\
20.56\end{array}$ & $\begin{array}{l}550.5 \\
486.3\end{array}$ & .... do do & $\begin{array}{l}0.05-\mathrm{dmm} \text { cell (sat. } \\
\text { sol. in } \mathrm{CS}_{2} \text { ). }\end{array}$ & $\begin{array}{l}\text { Do. } \\
\text { 1,2,3-Trichloroben- } \\
\text { zene. }\end{array}$ \\
\hline $\begin{array}{l}21.52 \\
21.80\end{array}$ & $\begin{array}{l}464.6 \\
458.6\end{array}$ & _..... do & $\begin{array}{l}0.05-\mathrm{mm} \text { cell } \\
.025-\mathrm{mm} \text { cell }\end{array}$ & $\begin{array}{l}\text { Toluene. } \\
1,2,4-\text { Trichlor oben- } \\
\text { zene. }\end{array}$ \\
\hline${ }^{2} 22.76$ & 439.3 & 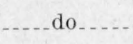 & do do .... & Do. \\
\hline 23.85 & 419.2 & Vapor.... & Atmospheric.... & Water. \\
\hline
\end{tabular}

sBroad bands.

piece of fairly fine plate glass, which is resting on a level surface. A doctor blade (number 15 for a film of $25 \mu$ in thickness) is drawn over the solution to make the film more nearly uniform in thickness. The film is then allowed to dry at room temperature; the surface should be protected from dust and other particles while drying. To remove the dried film 
from the glass plate water is applied, and the film readily floats off the glass. After the film is redried, it is ready for use. The thickness may be checked with either a Swedish gauge or a micrometer. In figure 2 are shown the bands of polystyrene in the region of $3.4 \mu$ as recorded with the lithium fluoride prism. Seven bands are observed in this region, and six have been selected for use in calibration. In figure 3 is shown the spectrum of a film of polystyrene from 2 to $16 \mu$. The grating instrument wavelength values of the bands selected for calibration have been marked on the curve, which was a record obtained from a Baird infrared spectrophotometer.

The trichlorobenzene samples, both highly purified and technical grades, were obtained from Hooker Electrochemical Co., Niagara Falls, N. Y. The authors are indebted to R. H. Kimball of that company for furnishing highly purified samples of both 1,2,3- and 1,2,4-trichlorobenzene. In figure 4 the spectrum from 1.5 to $2.5 \mu$ of highly purified $1,2,4-$ trichlorobenzene as obtained from the Perkin-Elmer $12-\mathrm{A}$ spectrometer with a lithium fluoride prism is shown. The seven bands that have been selected for the calibration have the wavelengths marked on the curve. These bands were not very broad even when measured on the grating instrument, and the region of maximum absorption could be determined to the fourth decimal place of wavelength in microns. Original grating instrument recorder traces of two bands of 1,2,4-trichlorobenzene in the 2 - $\mu$ region are given in figures 7 and 8 . The wavelength of the band at $1.6606 \mu$ was determined from the mercury emission lines superimposed on the spectrum. To achieve this a Cetron mercury lamp, similar to the S-1 sun lamp, was used as the source. By focussing one of the hot electrodes on the entrance slit, the absorption and emission spectra could be measured simultaneously. In the determination of a second band in this region, figure 8 , water vapor lines that appear on both sides of the band were used as standards. On these two figures the wavelengths of the reference lines have been indicated as well as the, wavelengths of the two bands of 1,2,4-trichlorobenzene.

The spectrum of technical grade 1,2,4-trichlorobenzene from 14 to $24 \mu$ as recorded by the PerkinElmer $12-\mathrm{A}$ spectrometer is shown with the wavelengths noted in figure 5. The technical grade contains some 1,2,3-trichlorobenzene, and some of the bands in the spectrum are due to the 1,2,3-isomer. In order to distinguish the bands that arise from the 1,2,4-trichlorobenzene and those from the 1,2,3trichlorobenzene, the spectra of highly purified samples of each of these isomers are shown in figure 6. The band at $20.56 \mu$ is seen to be due to $1,2,3$ trichlorobenzene. However, the band at $15.48 \mu$ does not appear in the spectra of either of the purified samples and thus probably arises from another chlorobenzene contained in the technical grade 1,2,4-trichlorobenzene. Although the results are not shown here, a mixture of about 85 percent of 1,2,4-trichlorobenzene and about 15 percent of 1,2,3-trichlorobenzene was also measured from 14 to $24 \mu$. No changes in the positions of the bands that were selected for calibration points were observed in the prism measurements when the spectrum of the mixture was compared with that of the technical grade 1,2,4-trichlorobenzene. The value of $22.76 \mu$ is a prism instrument determination and is probably accurate to $\pm 0.02 \mu$. As the path from the source to the detector for the grating instrument is greater than that for the prism instrument, the atmospheric water vapor absorption is also greater. This absorption in the region of the $22.76-\mu$ band makes it difficult to determine the position of the band, and thus the prism spectrometer value is given. The bands that are broad and not as accurately determined are listed in the table and are denoted as broad bands.

In table 1 is given a list of bands and emission lines that extend from 0.5 to $24 \mu$. All data not obtained in the current set of experiments are quoted from the sources listed. The absorption band of water vapor at $23.85 \mu$ is made up of several lines, and the listed value was obtained with low resolution of the grating spectrometer. The wavelengths are given in microns and the wave numbers in vacuum in $\mathrm{cm}^{-1}$. The reduction of the values of wave number to vacuum was accomplished by using 1.0002706 as the index of refraction of air. The index of refraction of air is not a constant, but the variation in the value is small and would introduce inappreciable changes in the wave number. The list includes bands measured in this work and other bands, which should give sufficient points for calibration of prism instruments. Additional wavelengths beyond those shown in the table are needed in some regions, and it is hoped that further measurements will be made in the future. This work has not included any measurements beyond $25 \mu$, but there are a large number of water vapor lines that are very well suited for calibration in this region $[6,7]$.

[1] G. Herzberg, Infrared and Raman spectra of polyatomic molecules (D. Van Nostrand Co., Inc., New York, N. Y., 1945).

[2] R. A. Oetjen, Chao-Lou Kao, and H. M. Randall, Rev. Sci. Instr. 13, 515 (1942).

[3] API Project No. 44, Spectrogram No. 369.

[4] Avis Borden and E. F. Barker, J. Chem. Phys. 6, 553 (1938).

[5] Curtis J. Humphreys, J. Opt. Soc. Am. 40, 255 (1950),

[6] H. M. Randall, D. M. Dennison, N. Ginsburg, and L. R. Weber, Phys. Rev. 52, 160 (1937).

[7] Earle K. Plyler, J. Research NBS 41, 125 (1948) RP 1911. 

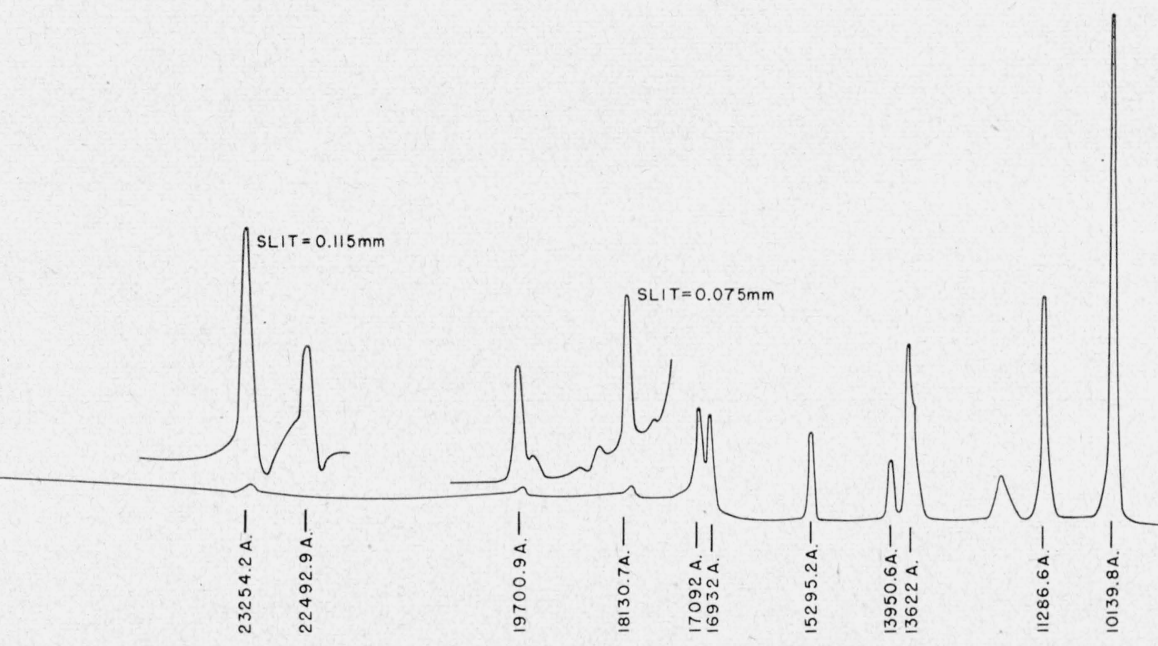

- WAVELENGTH

FiguRE 1. Mercury emission spectra in the region from 0.5 to $2.4 \mu$ as obtained from an $A H-4$ mercury lamp and a $12-A$ Perkin-Elmer spectrometer with a lithium fluoride prism.

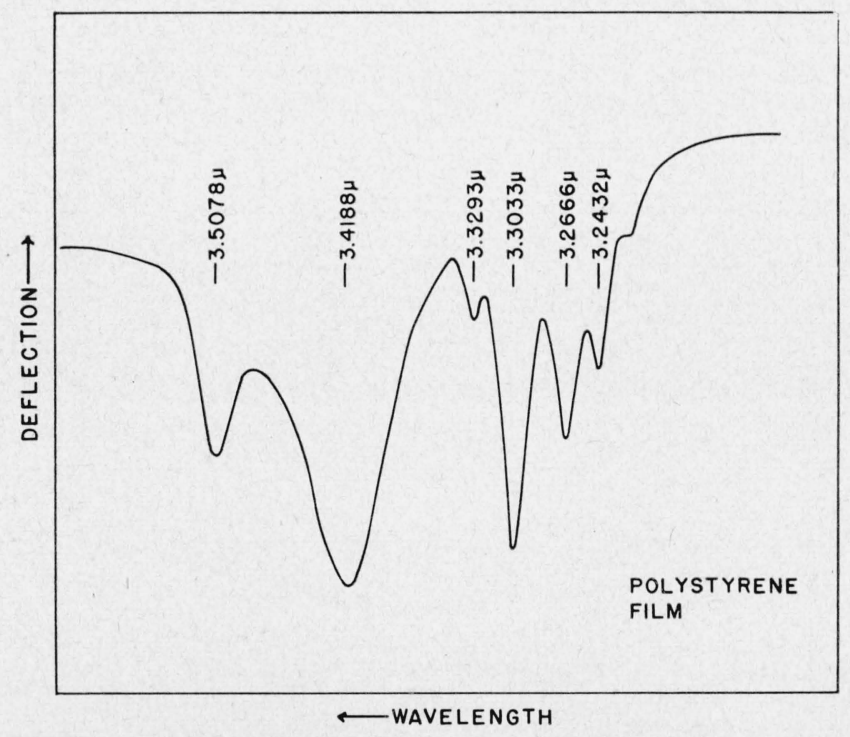

FiguRE 2. Infrared absorption bands of polystyrene in the region of $3.4 \mu$ for a film of about $25 \mu$ in thickness.

A lithium fluoride prism was used. 


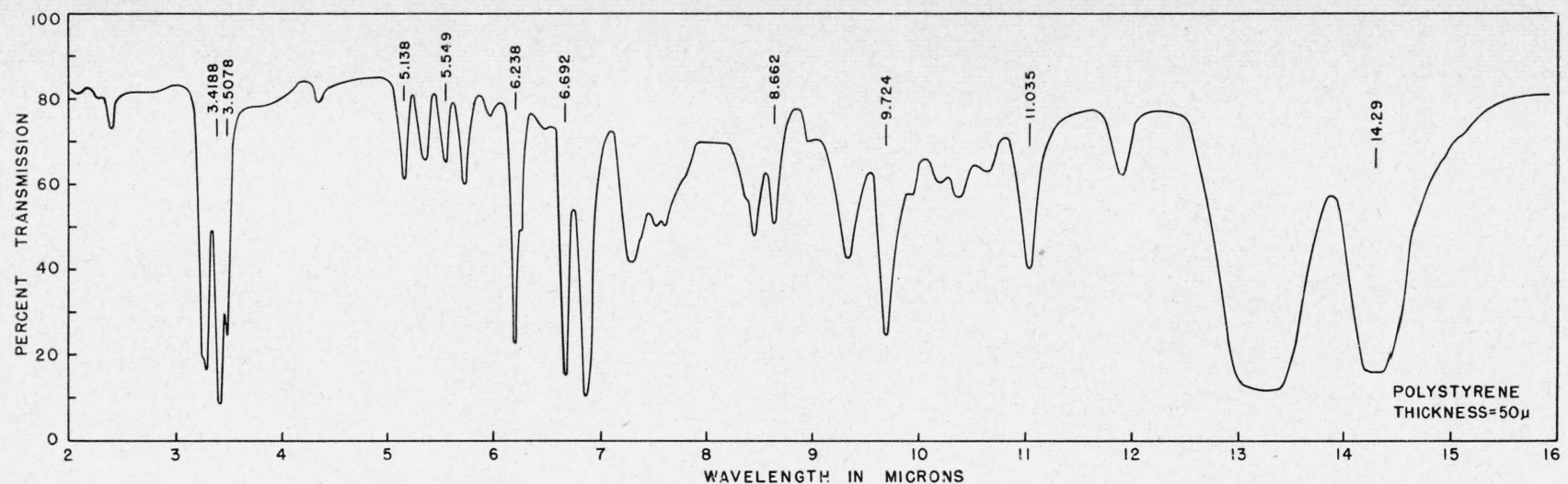

Figure 3. Infrared absorption spectrum from 2 to $16 \mu$ of a polystyrene film measured on a Baird Associates infrared spectrophotometer.

The bands that have been measured on a grating instrument are marked on the figure.

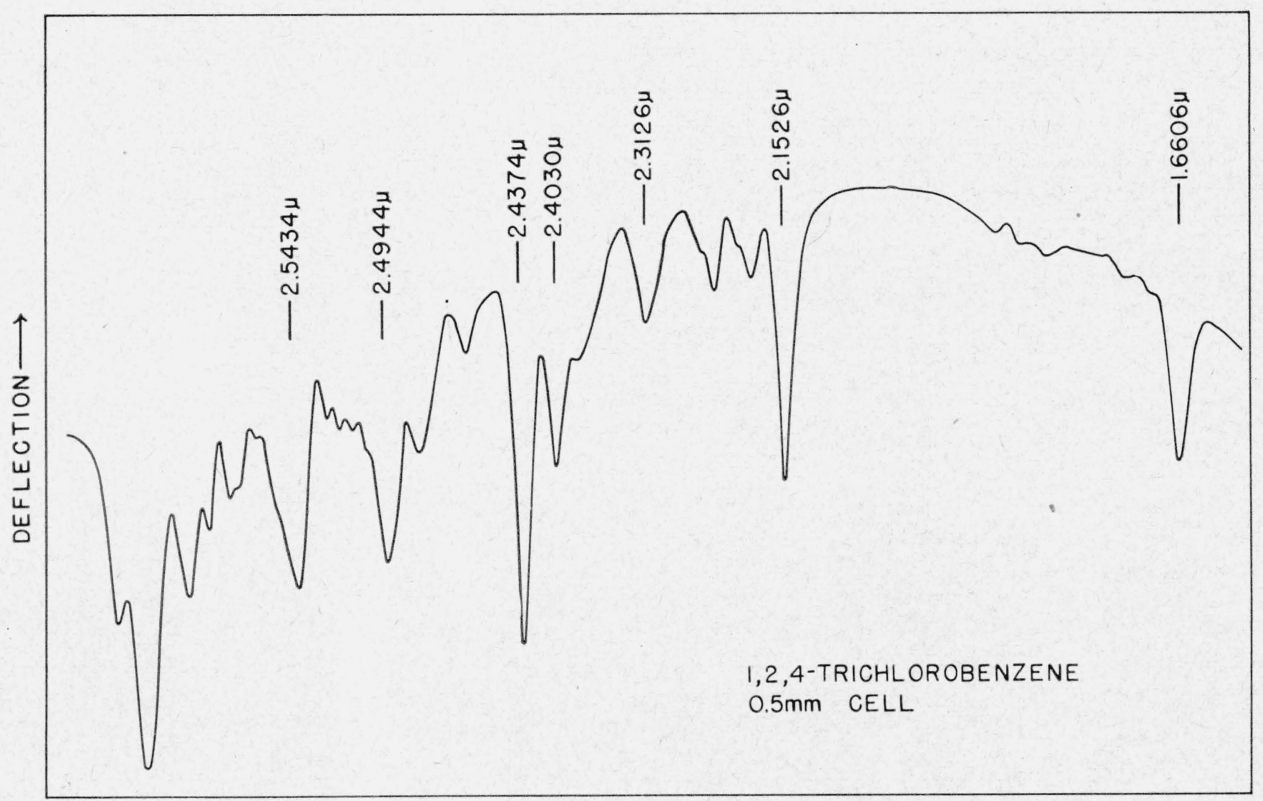

WAVELENGTH

FIGURE 4. Infrared absorption spectrum of highly purified 1,2,4-trichlorobenzene as measured with the lithium fluorid prisme.

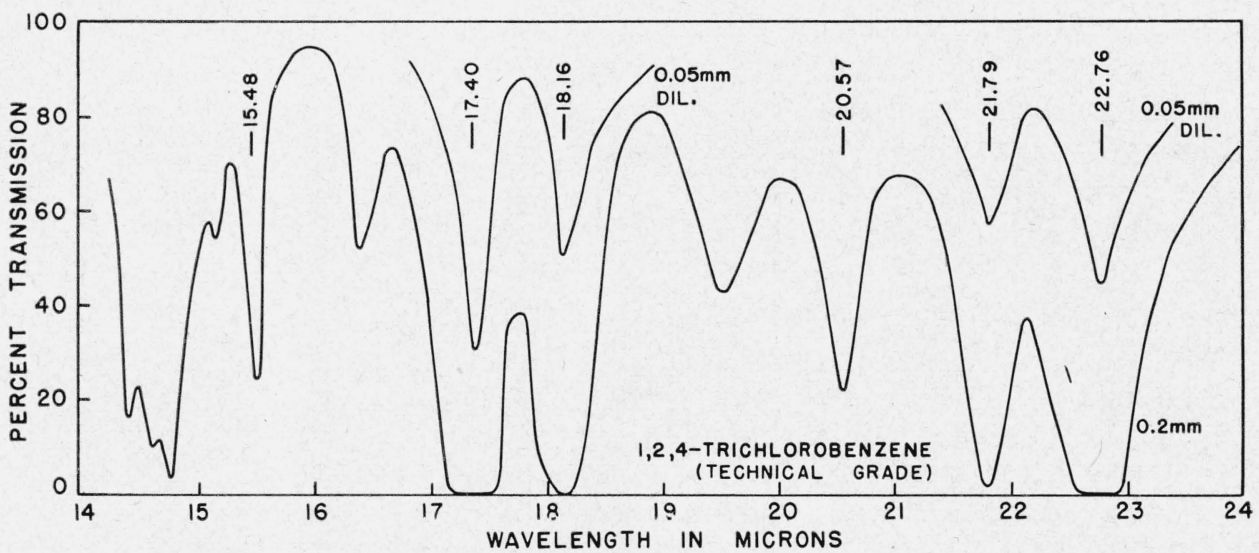

Figure 5. Infrared absorption 'spectrum of 1,2,4-trichlorobenzene from 14 to $24 \mu$.

The inserts were obtained by diluting the trichlorobenzene $1: 4$ in carbon disulfide. 


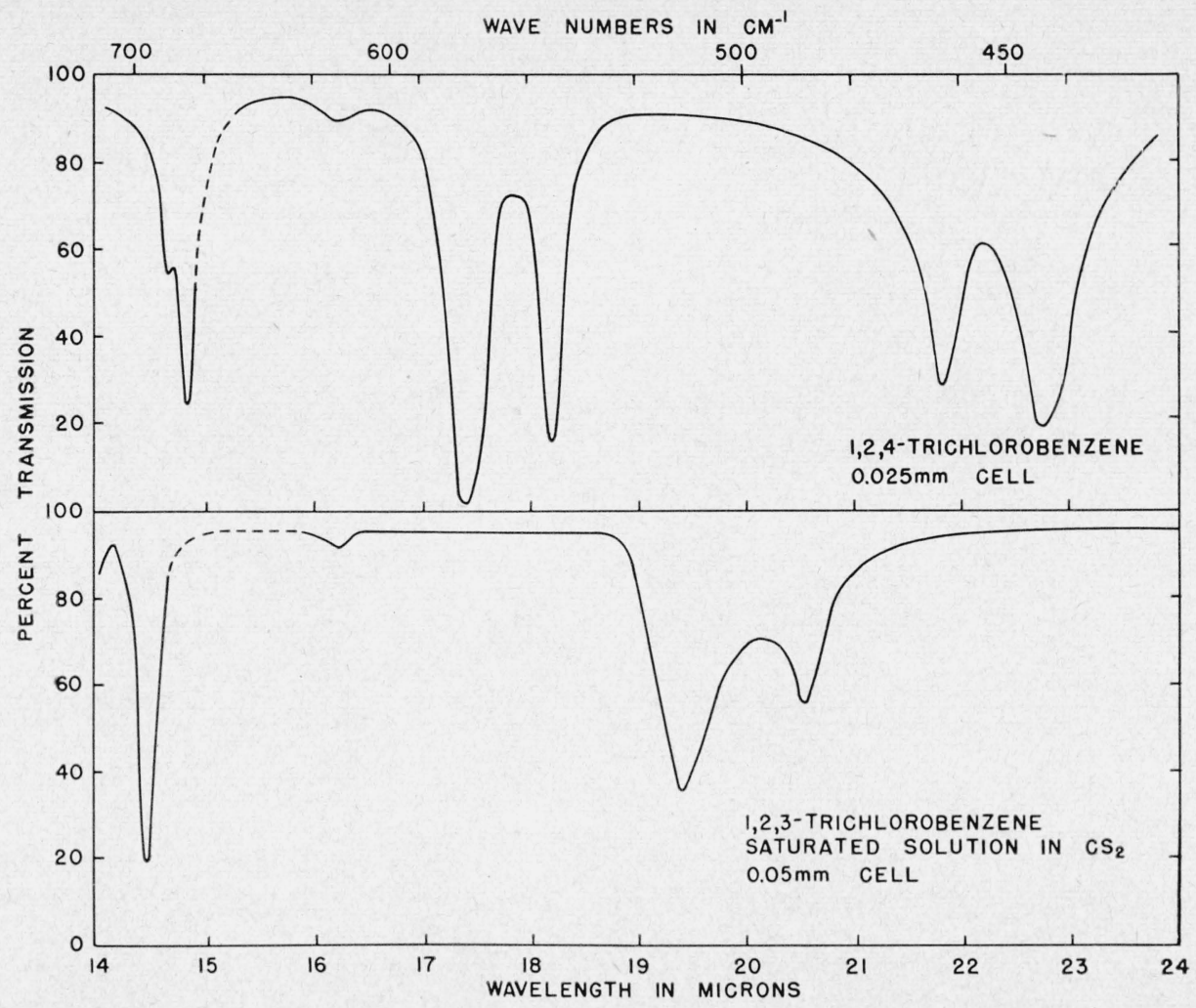

FIGURE 6. Infrared spectra from 14 to $24 \mu$ of highly purified samples of 1,2,4-trichlorobenzene and 1,2,3-trichlorobenzene.

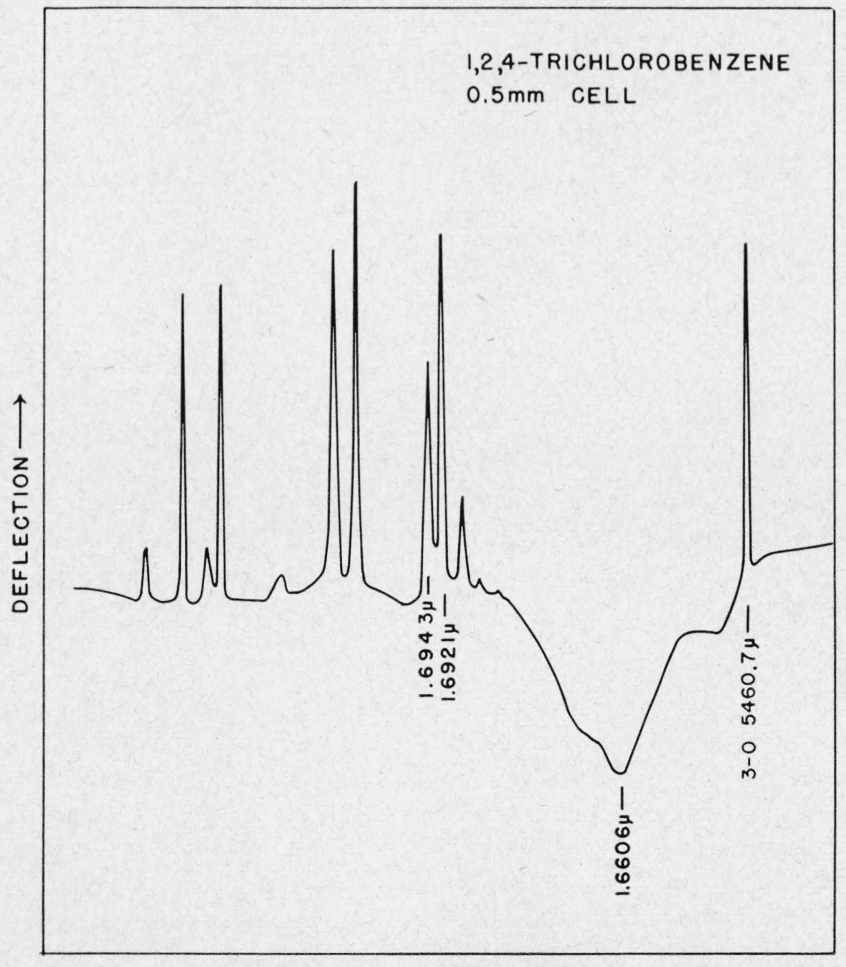

$\longleftarrow$ WAVELENGTH

FIGURE 7. Absorption band at $1.6606 \mu$ of 1,2,4-trichlorobenzene with mercury emission lines superimposed on the spectrum as obtained from the 15,000 lines-per-inch grating instrument. 


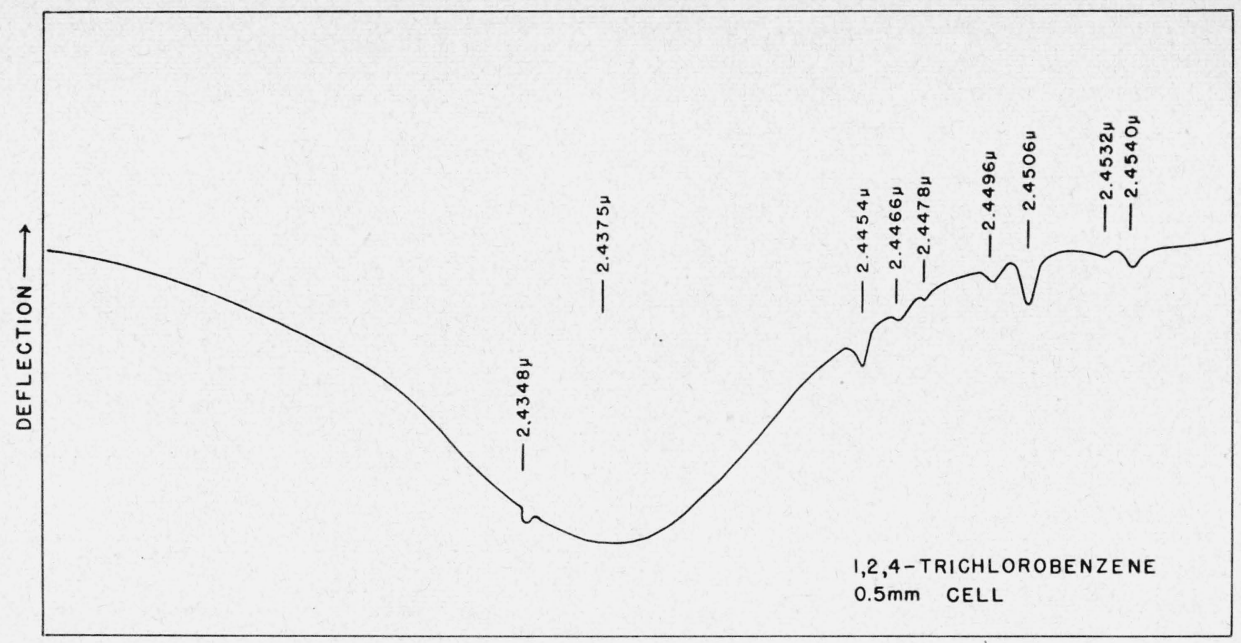

WAVELENGTH $\longrightarrow$

FiguRE 8. Absorption band at $2.4375 \mu$ of 1,2,4-trichlorobenzene with water vapor lines superimposed on the spectrum, as measured with the 15,000 lines-per-inch grating instrument.

Washington, August 29, 1950

\title{
High-Pressure Apparatus for Compressibility Studies and its Application to Measurements on Leather and Collagen
}

\author{
By Charles E. Weir
}

\begin{abstract}
The design and construction of apparatus to be used to measure volume changes of solids (or liquids) between 1,000- and 10,000-atmosphere pressure is described in detail. Calibration of the equipment and its use in determining the compression $\left(-\Delta V / V_{0}\right)$ of leather are discussed. The compression of leather between 1,000 and 10,000 atmospheres is reported. The compression between 2,000- and 10,000-atmosphere pressure is approximately 7 percent and appears to be relatively unaffected by moisture content, type of tannage, or sample variation. The compression of all leathers tested is described by the equation $-\Delta V / V_{0}=$ $1.23 \times 10^{-5}(P-2000)-5.60 \times 10^{-10}(P-2000)^{2}+1.35 \times 10^{-14}(P-2000)^{3}$.
\end{abstract}

\section{Introduction}

A Bureau program of measurement of physical constants of leather and collagen has resulted in a determination of the expansivity of leather and collagen [1]. ${ }^{1}$ These experiments also demonstrated that the shrinkage of leather, heretofore considered as analogous to a melting, was in reality a phenomenon occurring over a range of temperatures and resulted in an increase in real volume of the leatherwater system studied. Subsequent studies on the rate of shrinkage as a function of temperature, tannage, liquid medium, etc., have been reported $[2,3]$. In view of the results an investigation of the effect of pressure on leather and the shrinkage process was indicated, including a determination of the compressibility of leather for which only estimates have been available [4].

Experiments involving appreciable pressures are extremely exacting mechanically and have been

\footnotetext{
${ }_{1}$ Figures in brackets indicate the literature references at the end of this paper.
}

performed in few laboratories. To obtain information on the apparatus and techniques involved in such measurements, preliminary experiments were conducted on equipment that has been used for many years in the Geophysical Laboratory of the Carnegie Institution of Washington, for measurements at pressures as high as 12,000 bars. Subsequently similar equipment has been constructed at this Bureau and used in conjunction with a hydraulic press in the Geophysical Laboratory. This report deals with a description of the apparatus and a part of the data obtained.

\section{Apparatus}

In theory the apparatus required is simple; in practice, however, limitations imposed by the strength of materials require exacting machine work and the best of materials. An experiment consists essentially of forcing a piston into a vessel containing the sample under study immersed in a suitable liquid, and record- 